\title{
Edward A. Steiner and the Struggle for Toleration During World War I
}

\author{
David W. JORDAN
}

The United States' entry into the First World War unleashed forces of prejudice against German-American citizens which made a mockery of the ideals that President Woodrow Wilson set forth of making the world safe for democracy. Americans renamed German measles "victory measles" and sauerkraut became "victory cabbage." These early changes, relatively harmless in themselves, were only the first surface manifestations of potentially sinister tendencies which needed little prodding to victimize citizens of Central Powers' ancestry through ostracism, harrassment, and actual physical abuse. Most "hyphenated Americans," as recent immigrants and their children were often called, were powerless to defend themselves against this emotional pro-war propaganda and its consequences; even prominent Americans of recent immigrant origins found themselves the victims of a war hysteria which demanded a so-called $100 \%$ American. ${ }^{1}$

1. Frederick C. Luebke, Bonds of Loyalty: German-Americans and World War I (DeKalb, Illinois, 1974) provides the fullest coverage of this response to the war. The most notorious example of anti-German hysteria was the lynching of an innocent victim, Robert Prager, in Collinsville, Illinois, in April 1918. A jury unanimously found his acknowledged killers not guilty. Ibid., 3-24. 
Edward A. Steiner, professor of religion at Grinnell College in Iowa, became one highly publicized target of this emotionalism. A state-wide campaign vilified his ancestry, branded him a "slacker," and questioned his patriotism. A well known proponent of the Social Gospel movement and a recognized spokesman on the immigrant question, Steiner spoke out vigorously for the rights of all American citizens whose allegiance of their country was under attack; he fought back against those critics who labeled him as disloyal and sought to have him removed from his teaching position. By the end of the war, Steiner had become the focus of a nationwide campaign for justice, and his is an excellent case study of the negative fallout from the domestic impact of war.

Edward Steiner was born into a Jewish family in the Slovakia area of Austria. He grew up in a staunchly antimilitaristic family and lost both his father and an older brother in wars of the Austro-Hungarian Empire. By the time Steiner entered the University of Heidelberg, his emerging convictions against nationalism and war proved highly receptive to the writings of Leo Tolstoy. Steiner became an avid disciple of the influential Russian and traveled across eastern Europe, mostly on foot, to meet the famous writer. This journey became the first of numerous pilgrimages to Russia during which he studied with the master and embraced his creed. Steiner, like Tolstoy, became drawn particularly to the Sermon on the Mount, the ideal of the peacemaker, and Jesus' admonition found in Matthew 5:39 "That ye resist not evil," but always turn the other cheek.

The young Jewish student immigrated to the United States in 1886, largely to avoid military conscription. His evolving philosophical commitment to non-violence, tolerance, and brotherly love underwent a further critical change with his conversion to Christianity soon thereafter. The full circumstances of this important religious crisis remain uncertain, but Steiner subsequently enrolled at Oberlin where he continued his education and later entered the ministry. He proceeded to acquire a national reputation in religious circles which led to his appointment in 1903 as the Rand Professor of Applied Christianity at Grinnell. From his classroom, Steiner influenced many students 
to adopt a great concern for the less fortunate, especially the increasing numbers of eastern and southern European immigrants to America, and he steered a number of young people into settlement-house work. Steiner extended his influence through a six-month lecture tour each winter and spring and through the frequent publication of magazine articles and books, many of which promulgated his views favoring international and interpersonal cooperation and opposing the use of violence. ${ }^{2}$

The outbreak of war in Europe in 1914 posed then a serious intellectual and religious dilemma for Steiner. As a former subject of the Austrian emperor, Steiner sympathized with those people opposing autocratic regimes and struggling for greater social justice. He had no kind words for the Austrian or German governments, but his Christian beliefs and his pacifism counseled opposition to war and to the passions it spawned. As long as the United States remained neutral, a position which Steiner favored, he could avoid the ultimate resolution of his conflicting convictions. Even during the first three years of the war, however, Steiner found it difficult to remain silent as proponents of preparedness urged American entry and increasingly attacked immigrants as the primary resisters of war. In 1916, Steiner delivered before the League on Political Education in New York City a passionate address entitled "The Confession of a Hyphenated American." 3 Steiner eloquently warned against the dangers of war in arousing an unquestioning sympathy with one's own people and an irrational antipathy to their foes. The ideal of internationalism, to which he was devoutly committed, would certainly suffer. Steiner particularly defended the immigrant community against current attacks. "I plead guilty to

2. Steiner deserves fuller biographical treatment. This brief sketch of his life draws primarily on newspaper clippings and correspondence in the Steiner Papers, Grinnell College Archives, Grinnell, Iowa, and on his extensive autobiographical writings, especially Against the Current: Simple Chapters From a Complex Life (New York, 1910); From Alien to Citizen (New York, 1914); and The Eternal Hunger (New York, 1925). Steiner wrote a popular biography of his hero entitled Tolstoy the Man (1903; reissued and expanded, New York, 1908). Steiner made at least six trips to visit Tolstoy over the years.

3. Edward A. Steiner, The Confession of a Hyphenated American (New York, 1916), with passages quoted below appearing on pp. 7, 22, 39-40, and 47-48. 
the charge of being a hyphenated American," he said. "I am proud of the fact and happy in it."

Hyphenated Americans, while unable to control where they were born, had consciously moved to the United States, and in Steiner's estimation such people provided the greatest possibility for realizing democratic ideals in this country. Conversely, he argued, the "real treason against the democratic ideals of America has been committed not on the East Side of New York but on the West Side. I find more real patriotism on Fifth Street than on Fifth Avenue, and if government by the people, of the people, and for the people,' perishes from the earth, it will perish from the exclusive suburb down, and not from the inclusive ghetto up." Professing "nothing but loathing for this 'foul and unthinkable war," Steiner refused "to be patriotic in the European sense-which means to believe everything bad about other nations and nothing but good about your own and to hate with desperate hatred the people living yonder, where they have painted another colour on the customhouse barrier." Steiner denounced the mounting wave of antiGerman hostility and concluded, "I do not believe in war; not until every resource to settle the difficulty without it has been exhausted. If, however, war should come and the vital interests of the nation be attacked, if this government were in danger of perishing from the earth, I and my son would stand somewhere in the line, just as countless 'hyphenated Americans' and their children would, even if we have to face our own brothers, who come to do the brutal bidding of their monarchs."

Woodrow Wilson's request the following April for Congress to declare war on Germany brought Steiner's personal crisis to a head. Just days after the president's war message, Steiner delivered a chapel address to Grinnell's students and appealed, "Let us enter this war solemnly and peacefully." "Reluctantly," he later wrote, "I yielded myself to the thought of my country's entrance into the war." With "a heavy heart," Steiner endorsed Wilson's call for support of what the professor understood as a defensive war. He even convinced himself gradually over the next few months that the war might significantly improve the lives of many people throughout the world. As he told the graduating class of Iowa State College at 
Ames in June, he unalterably opposed autocratic regimes and hoped this war would help to realize the democratic aspirations of many Europeans. ${ }^{4}$

The war mood of which Steiner had ominously spoken in 1916 soon caused the 51-year-old man even greater concern. The government's program to rally enthusiasm for the war disturbingly intensified the already widespread hostility toward German-Americans. As persecution became more vicious in Iowa and elsewhere, Steiner concluded the greatest service he could render in the war effort would be to "act as mediator between the alien born and the native citizen." He decided to defend publicly those unjustly under attack and to campaign openly for a more tolerant approach to the war and the problems it was provoking in the country. ${ }^{5}$

During the summer of 1917, Steiner, speaking frequently before student groups, churches, and lyceums, called repeatedly for Americans, especially Christian Americans, not to hate the enemy or the suspected enemy. While proclaiming full support for the war effort, Steiner tried dispassionately to show that the current German government and the German people historically were not the same. He defended significant contributions by Germans to the world's culture and civilization and opposed those who would abruptly dismiss those legacies as products of the hated Hun and would ban music by German composers from concert halls. Caring Americans, he argued before numerous Iowans, should approach sympathetically the sizable German-American population within the state. Steiner explicitly denounced the vigilante activity of the self-proclaimed patriots in Iowa who recently had dragged a man from his bed, stripped him of his clothes, and compelled him publicly to kiss the American flag, an action Steiner pronounced as a "desecration of the flag itself and a betrayal of the American spirit." 6

4. Scarlet and Black (college newspaper), 7 April 1917; Edward A. Steiner, "A Wrong Strategy," The Outlook 118 (2 January 1918), 14-15; Des Moines Register, 4 June 1917.

5. Steiner recounted the progress of his thought and actions in articles which he later wrote in response to the attacks on his loyalty. See particularly Steiner, "Wrong Strategy."

6. Ibid. For an account of a similar flag-kissing incident later in 1917, see the Des Moines Capital, 20 November 1917. 
These addresses and Steiner's emotional accounts of his own personal dilemma moved many of his listeners during the summer and early autumn. The state magazine for the Congregational church in Iowa commended his stand and praised Steiner as a "son of Israel who . . . is no minor prophet," a man who "will fight in a defensive war for the United States, if need be, tho hating war with perfect hatred."7 Such public support became rare, however, as popular sentiment increasingly responded to other appeals and embraced the extremes of antiGerman emotionalism. A baccalaureate address to the graduating class of Newton High School in June brought angry rejoinders in that community's paper. Through the fall, more and more Iowans commented unfavorably on the disturbing language and ideas of the professor from Grinnell. Finally, two lectures in Marshalltown and Marengo in October and November stirred considerable controversy and galvanized a concerted opposition. ${ }^{8}$

The editors of the Des Moines Capital decided the time had come to expose Steiner for what they believed he really was, a disloyal American. The Capital had long supported the war and an unquestioning patriotism on the part of Americans; it openly marshalled opinion through editorials and news stories against an array of "slackers," a label which encompassed anyone who seemed to have the slightest reservations about America's role in the crusade or who had any kind word for Germany or things German. Endorsing the goals of the National Security League and its even more conservative offshoot, the American Defense Society, the Capital by November was focusing on two primary goals - the elimination of the German language and anything else German from the curricula of America's schools and a

\section{Quoted in The Grinnell Review 12 (May 1917), 153.}

8. In June, Steiner told a vespers' audience at the college that America's most valuable assets were her great ideals, and that the challenge of the war was to make a reality of the idea of more democratic world. A campus talk in November conveyed his conviction that he could have "no faith in any concert of world powers in which Jesus of Nazareth has no place." Scarlet and Black, 13 June, 14 November 1917. For accounts of other addresses, see the Des Moines Capital, 22 November, 31 December 1917; Newton Daily News, 1 June 1917; and undated, unlabeled newspaper clippings in the Steiner Papers. 
careful investigation of the loyalty of teachers and professors. Patriotic groups had frequently contended it was a definite policy of German propaganda to infiltrate the ranks of America's schools and colleges in order to criticize democracy and to promote the goals of Germany. For members of these organizations and now particularly for the editors of the Capital, Professor Steiner became the primary target of suspicion in Iowa.

The Capital launched its vituperative attack in an editorial published November 29 entitled "Dr. Steiner Must Amend his Patriotism." The paper charged that Steiner's lectures throughout the state were particularly dangerous because he was a well known orator "with a wonderful command of languages" and able to "deliver a brilliant address." The editors feared that unsuspecting audiences might fall under Steiner's sway without realizing his so-called patriotic addresses "are patriotic in name only." Moreover, Steiner had allegedly remarked at Marengo that "Civilization is in no more danger from Prussian militarism than from the Bank of England." The editorial concluded that "There can be no halfbreed patriotism in this country from now on. The man who desires to save the United States must make it known that we will have no more so-called German 'kultur.' "9

Steiner responded almost immediately in a letter to the editor of the Capital, declaring his unflinching loyalty. He stressed his own support for the war and related how American officials had even publicly praised his brother, still a resident of Europe, for his aid to the Allied cause. Steiner also clarified the Capital's misquoting of his remarks at Marengo. The actual statement had been "You cannot build your civilization upon an unrestrained militarism, neither can you build it on an unrestrained commercialism. Neither Potsdam, nor the Bank of England, nor Wall Street are safe foundations. There is only one

9. Des Moines Capital, 19 November 1917. Luebke, Bonds of Loyalty, and Robert K. Murray, Red Scare (Minneapolis, 1955), treat the National Security League and the American Defense Society. For an example of the inflammatory and influential literature of these organizations, see Earl E. Sperry, The Tentacles of the German Octopus in America, Patriotism Through Education Series, No. 21 (New York, n.d.). 
foundation, and that has been laid in the tragedy of Calvary." "If this is seditious, or half-hearted patriotism," Steiner declared, "it must stand and I will take the consequences." The Capital, Steiner continued, had a task to arouse the nation to the danger without, a task he noted it was undertaking "with fervour, if not always with wisdom." Steiner's own task was to "point out the danger within," and to warn against waging the war on "a lower level" than that announced by Wilson. Steiner vowed to share in any sacrifice, down to "my last penny, and my last drop of blood," but he vowed "one thing I will not do and cannot do, I will not by word or deed increase the hate which is in the world. I cannot so amend my patriotism that it will nullify my Christianity. My soul is still my own and my God's. My money and my body my country can claim at anytime."10

The Capital printed Steiner's impassioned rejoinder, but in a follow-up editorial asserted that on the basis of "the doctor's own report of his own utterances we declare his speech [in Marengo] to be unpatriotic." Steiner remained an "apologist for Germany," a man who gives too little attention to German faults and too much to those of America. "This is the fashionable way with many whom we call pro-German," the editorial observed. ${ }^{11}$

As opinions hardened throughout the nation on such issues, Iowans in subsequent weeks similarly drew the lines on Edward Steiner's patriotism. Assuming the vanguard in the professor's defense was the Capital's rival, the Des Moines Register. More restrained on the current war hysteria, this paper still enthusiastically supported the war. Where the Capital frequently railed against the teaching of German language, the Register defended its place in the public schools. Where the Capital denounced all things German, the Register reminded its readers of the many positive gifts of Germans and called for a distinction between the music of Beethoven and the political policies of the Kaiser. Now as the Capital besmirched Steiner's reputation, the Register responded in his defense.

10. Des Moines Capital, 8 December 1917. The paper delayed printing the letter for several days after receiving it.

11. Ibid. See also another follow-up editorial to the original attack published 6 December 1917. 
An editorial on December 3 picked up the Capital's gauntlet. The Register saw no reason to hold against Steiner anything "he may think or feel with regard to the eastern question." The editors observed that they knew of no man of foreign birth who had done more to popularize American ideals in Europe, and the paper left no doubt of its endorsement of Steiner's loyalty..$^{12}$

Opposite the editorial appeared a column by Steiner himself entitled "Wanted: A New Strategy." Probably at the invitation of the editors, Steiner presented an extended defense of his position. He explained his turmoil of recent months and his righteous indignation at the treatment of German-Americans and the personal attacks upon himself. "If I were not so thoroughly an American," he wrote, "the treatment I have received would make an anarchist out of me. I am pleading for a new strategy, for we are unmaking good Americans and not making them." Slightly modified, the column also appeared a few weeks later in The Outlook, a national journal. Here, too, the magazine's editors explained that Steiner had come under attack and those familiar with him were entitled to his statement of defense. Again, there was little doubt of the opinion of the editors, who spoke positively of Steiner and expressed the hope that his essay "will lead to a more discriminating valuation of the Americanism that has been fostered by Americans of alien birth."13

Steiner gained the opportunity for a public audience soon after the issue exploded in the state press. Large crowds turned out to hear him speak at Camp Dodge in response to an invitation issued after the Capital's editorial had appeared. Predictably, Steiner's defenders found the address acceptable and indicative of his patriotism; his opponents remained unsatisfied even by a much milder expression of opinion than Steiner usually voiced. ${ }^{14}$

12. Des Moines Register, 3 December 1917 and passim throughout the earlier months.

13. Des Moines Register, 3 December 1917; Steiner, "Wrong Strategy," 14-15.

14. Des Moines Register, 1 December 1917; Des Moines Capital, 4, 6 December 1917. 
The editorial pages of the two Des Moines papers became a battleground in subsequent days. Readers from across the state voiced their opinions in letters to the editors, and editorials from other papers were condensed and reprinted. Those individuals writing to the Register disproportionately supported Steiner, while his detractors expressed their sentiments more frequently to the Capital. The editors re-entered the fray themselves in late December. The Capital particularly restated its full case, emphasizing that Steiner's "opportunities for doing good or harm are great because he is a professor at Grinnell College." The editorial concluded, "We have stated our suspicions of Dr. Steiner. We have nothing to retract."15

\section{A}

MORE IMMEdiate battle for Steiner existed in his home community of Grinnell. The volume of the statewide attacks on his integrity and his new notoriety prompted the professor to submit his resignation to President John H. T. Main, the man who had been instrumental in hiring Steiner fourteen years earlier. Main emphatically rejected the resignation. Both Main and the college's faculty "stated their absolute faith in Professor Steiner and in his loyalty to the nation," but their unequivocal support failed to quell local suspicions in the community or to end the controversy. ${ }^{16}$ Steiner temporarily left town the first week in December to speak in Carnegie Hall and at the Old South Church in New York on the immigrant question. In his absence, the campus newspaper, the Scarlet and Black, voiced its full confidence in the professor's loyalty and former students signed a petition in his behalf. ${ }^{17}$

The two local biweekly papers, both Republican in their political orientation, took different paths in reporting the con-

15. Letters from all over the state attacking Steiner often exceeded the position of the Capital in emotionalism; one writer from Grinnell even spoke of the paper's "mild attack" on the professor and called for a stronger antiSteiner position. For the continuing appearance of these letters, see the editorial pages of the paper throughout December, and clippings in the Steiner Papers. The quotation appears in a summary editorial printed 1 January 1918.

16. Scarlet and Black, 5 December 1917.

17. Ibid., 8 December (lecture plans), 15 December (editorial supporting Steiner); see also the Grinnell Herald, 11 December 1917. 
troversy. The Grinnell Register, long a supporter of the more progressive wing of the GOP and now strongly pro-war, paralleled the Des Moines Register in a position highly favorable to Steiner. It did not editorialize on the subject, but prominently displayed the college's endorsement of Steiner as its December 3 lead story and an editorial in the same issue did commend the loyalty of German-Americans. In subsequent issues, the paper printed numerous articles favorable to the professor and carefully included the many endorsements which supported his patriotism. ${ }^{18}$

The rival paper, the Grinnell Herald, ignored President Main's statement of support for Steiner and in the next three months rarely printed any of the numerous endorsements of Steiner's loyalty. Instead, it editorialized frequently against Steiner's positions. Without mentioning him personally by name - such direct attacks were not the style of this or most small-town newspapers, especially when the college was so important in the community - the Herald made explicit its alliance with the Capital and further encouraged local distrust of Steiner. On December 7, the editor lashed out against the teaching of German at the Grinnell High School, citing this issue as "one test of patriotism." As another test, neither the schools of Grinnell nor the college "should pay American money to men who are not thorough patriots every day in the year and every hour in the day. . . . In Grinnell and Grinnell College there should be no false note. All professors cannot join the army. Some have done so. But they can see to it that no false ideas are spread of our duty to a nation with which we are at war." The editor returned to this and similar themes throughout the month. Specifically praising the Capital's leadership in such campaigns, he said no public utterance should contain anything which might give comfort to the enemy. ${ }^{19}$

18. See, for example, the Grinnell Register, 3, 31 December 1917; 3, 28 January; 4, 25 February; 21 March 1918. Leo Berenstain, "The Grinnell Herald and the Breakdown of the Republican Party, 1908-1912" (unpublished paper, Grinnell College Archives) examines both papers and their political stances in the immediate pre-war period.

19. Grinnell Herald, especially issues of 7, 11, 14 December 1917; 8, 29 January; 1, 15, 22, 26 February; and 22 March 1918. 
Spurred by this encouragement and probably abetted by individuals from Des Moines, a group of local businessmen met in late December to form a Citizen's Vigilance Corps at the request of the American Defense Society. The organization was open to any citizen with the payment of a one-dollar membership fee, but the press announcement stressed that the meetings "will naturally be secret." The group intended to investigate any seditious utterances or rumors of disloyalty. Clearly the Steiner case had precipitated the founding of this organization and immediately became its first order of business. The new overseers of local patriotism also promptly advised all Grinnellians with any pro-German sympathies "to keep their mouths shut."20

The editor of the Herald welcomed the organization as a positive development and declared in still another editorial on patriotism:

How worse than folly then to tell our boys and our brothers just as they are shouldering muskets to take their places in the trenches, that we and they must remember the good things our enemies have done, must obey the divine injunction to love our enemies and pray for them as we line up to mow them down with shrapnel and machine gun fire.

Any pro-German admonitions or any pacifist talk hampered the war cause, the editor observed. "This is a day of Americanism. No other propaganda should be tolerated." A few weeks later, he editorialized again that all truly patriotic people in Grinnell should join the Vigilance Corps. Eventually about one hundred townspeople did so. ${ }^{21}$

During the first two weeks in January, the Corps proceeded to investigate Steiner's loyalty. The professor hurriedly was preparing to depart for his annual lecture tour, but the escalating campaign against him necessitated more assertive action in his defense. He voluntarily met with the executive committee of the Corps. ${ }^{22}$ Meanwhile, appeals went out to friends across the country to write in his behalf. The most important response came from former president Theodore Roosevelt,

20. Ibid., 28 December 1917.

21. Ibid., 8 January (quote); 1 February 1918.

22. Grinnell Register, 21 January 1918. 
whom the American Defense Society proudly claimed as its honorary president. Roosevelt, who had frequently disagreed publicly with Steiner on political issues, nonetheless telegraphed on January 2 that "From all I know of you and your writing I am sure you are entirely loyal." He promised to mail soon a fuller statement of his support. ${ }^{23}$

Other endorsements from across the state and nation followed Roosevelt's in proclaiming Steiner's patriotism. Attempting further to dispel suspicion, the Grinnell College faculty on January 15 also adopted a strong resolution setting forth the solemn duty of every American to sacrifice and to work to the limits of his ability, and if need be to bear arms, in order to win the war. Steiner signed the resolution, as did every one of his colleagues. ${ }^{24}$

Roosevelt's telegram and these other professions of loyalty, along with Steiner's personal meeting with the executive committee of the Corps, persuaded that body's leadership to clear the accused's name, provided he would address the entire group with a suitably patriotic message. When scheduling complications, or some other unspecified reasons, prevented that speaking engagement in the next two weeks before Steiner's departure on his lecture tour, however, the disgruntled full membership of the Grinnell Vigilance Corps officially went on record January 19 that it could not "extend the word loyalty to Mr. Steiner."25

Faculty colleagues once more rallied to Steiner's defense. On February 11, they unanimously adopted another resolution, this time specifically expressing "to Professor Steiner their sympathy in view of the unjust attacks upon him and their confidence in his genuine Americanism and loyalty." Ironically, John P. Ryan, a faculty colleague, also served as president of the Vigilance Corps which was indisputably the most powerful

23. Scarlet and Black, 8 January 1918; Grinnell Register, 3 January 1918; on Roosevelt and the American Defense Society, see Luebke, Bonds of Loyalty, 216. The Steiner Papers contain other testimonials to the professor.

24. Minutes of Faculty Meetings, 15 January 1918, Grinnell College Archives.

25. Grinnell Register, 21 January 1918; Scarlet and Black, 26 January 1918; Des Moines Capital, 6 February 1918; and Grinnell Herald, 22 January, 5 February 1918. 
local force working to discredit Steiner. It is not clear whether or not Ryan was present and voting that day. ${ }^{26}$

The momentum had clearly shifted again to Steiner's critics. With the Corps branding Steiner as uncertifiably loyal, emotionalism in Grinnell got further out of hand. Open season on "slackers" commenced, as citizens moved beyond mere vigilance to vigilantism, often conducted anonymously at night. Where townspeople earlier in the controversy had deliberately crossed the street to avoid speaking to Steiner, some opponents now gave the professor's home a coat of yellow paint. The residences of other suspected patriots received a similar treatment, and in nearby Montezuma, individuals broke into the local schoolhouse, gathered up all the German books, and burned them. ${ }^{27}$

The Capital prominently reported the Corps' action against Steiner, but failed to cover the endorsements clearing his name. Other papers, however, in late January, February, and early March noted the endorsement of Steiner by the Grinnell chapter of the Daughters of the American Revolution and the invitation from the Liberty Loan office for Steiner to participate actively in its next campaign. From Denver, where Steiner had recently spoken to the local Teachers' Club came high praise and the tribute, "We have learned from you a deeper and truer patriotism."28

Still, such endorsements fell short of satisfactorily redeeming Steiner's reputation. Friends in the social justice movement, led by Julia Lathrop, the chief of the national Children's Bureau, sought a strong supportive statement from Woodrow Wilson himself. Joseph Tumulty, the president's secretary, advised

26. Minutes of Faculty Meetings, 11 February 1918; Grinnell Herald, 1 February 1918.

27. Grinnell Herald, 29 January 1918; Grinnell Register, 18 February 1918. Steiner in later years referred often to these snubs. Clippings, Steiner Papers. The press never identified the particular homes vandalized but local oral history traditions specifically mention Steiner as one of the victims. The Herald did oppose the painting.

28. Des Moines Capital, 6 February 1918; Grinnell Register, 25 February 1918; Grinnell Herald, 15, 26 February 1918; undated clippings, Steiner Papers (Denver teachers' tribute). 


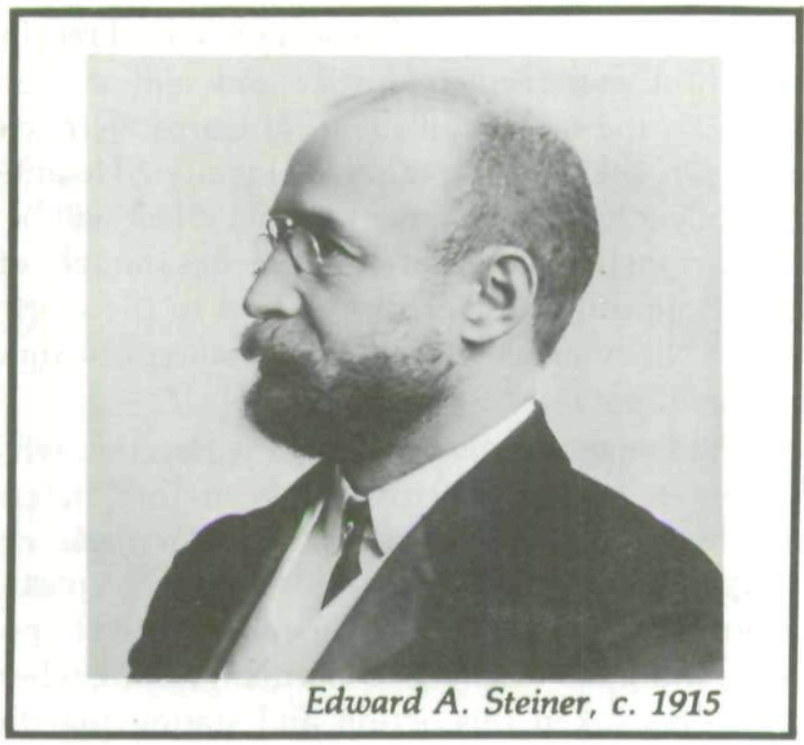

Lathrop of the impropriety of Wilson making direct statements in such cases, but the aide did arrange for Lathrop to receive from Bureau of Investigation in the Justice Department a statement regarding Steiner. A.B. Brelask, the chief of the bureau, prepared a written response for Lathrop on March 7. He indicated that some investigation of Steiner had followed upon the receipt of several complaints, and an agent had attended lectures delivered by the professor. Brelask observed, however, that there was "nothing in our files to indicate any tangible justification for accusing Professor Steiner of disloyalty." Lathrop immediately forwarded this letter to Mrs. Steiner, who had remained in Grinnell, and supporters of the professor prevailed upon the Herald to print the full correspondence; it also appeared in the Register. ${ }^{29}$

With such a positive clearance from the highest investigative agency in the nation, the local Vigilance Corps could hardly continue to proclaim Steiner's disloyalty. The Register pressed the case, asking Corps president Ryan for a specific statement. "The confusion and misunderstanding in the Steiner disloyalty charges are being rapidly cleared up to the satisfac-

29. Grinnell Register, 21 March 1918 (lead story); Grinnell Herald, 22 March 1918. 
tion of all parties," he reported. He acknowledged receipt of the letter from the Department of Justice and said at the present time, March 21, the records of the local Corps were "clear and favorable to Dr. Steiner as regards his loyalty." He anticipated "in a little while a formal statement to that effect will be sent to the press of Grinnell and the state. No one has thought of taking a position of opposition or of obstruction to the work of our government." No evidence of that formal statement survives, if it ever appeared. ${ }^{30}$

Steiner had never been indicted by the Register, which now closed its pages to the controversy with this statement of clearance. The Herald failed to report Ryan's remarks nor did it ever go beyond printing the letter from the Department of Justice. In subsequent months, the paper continued to pursue its goal of eliminating the teaching of German, noting where other communities had taken this action and stating that the local public schools and the college should follow suit. When a Quaker preacher in Bangor, Iowa, had his house painted yellow, not for seditious utterances but rather for the absence of patriotic statements, the Herald in effect supported this vigilante action and said, "All preachers and orators should get in line." 31

The local Vigilance Corps turned its attention as well to the question of German being taught. Combined efforts of the Herald and the Corps proved partially successful. In the fall of 1918, Grinnell public schools opened without a teacher of German. At the college, however, President Main refused to acquiesce. His enthusiastic support of the war was well known and unquestioned, yet he also staunchly maintained the propriety of continuing to teach the German language, history, and culture. ${ }^{32}$ The Herald made no editorial comment but later in the fall of 1918 it did attack Professor of History Charles Payne,

30. Grinnell Register, 21 March 1918.

31. Grinnell Herald, 29 March (quote), 5 April, 3 May, 25 June, 2 July, 13 August 1918.

32. Grinnell Herald, 20 August 1918. The Grinnell College Catalog, 1918-19, lists a full array of courses in German language, literature, and history. The previous year, the college took a strong stand in favor of such offerings; see "War and College Courses," The Grinnell Review 13 (October 
for an article in the student newspaper calling for Allied magnanimity in victory. The editor of the Herald demanded instead the sternest possible peace terms. ${ }^{33}$

Steiner returned to the community in time for the reopening of the new school year in September. The previous winter, sentiment against him had.been so strong, he had momentarily entertained the idea of leaving Grinnell permanently, especially after Boston College offered him an endowed chair "of United States Citizenship." In April, from his lecture tour, Steiner had written to Main and the trustees, stating his election to the chair, and inquiring "in view of certain charges and rumors in regard to his loyalty . . . if the Board wished him to continue his relation to Grinnell College or to sever it." The executive committee of the Board of Trustees had quickly expressed "its full confidence in his loyalty and unanimously voted to ask him to continue his relations with Grinnell." ${ }^{34}$ By the next fall, the controversy had subsided, but was by no means forgotten.

Steiner may have adopted a more cautious public stance in Grinnell and Iowa that autumn. There is no evidence of him issuing controversial statements during the remaining months of the war. ${ }^{35}$ By the following January, he was away once again, this time for an extended residence with his family on the Lower East Side of New York. Recently appointed by President Wilson

1917), 195-197. Main, in earlier opposing anti-war sentiment had stressed his own close ties to Germany. He wrote Iowa Senator Albert Cummins that "I owe to Germany my spiritual rebirth . . . I have spent some of the happiest days of my life in Germany," yet he wholeheartedly opposed the present German government and supported the war. Main to Cummins, 16 April 1917, Main Papers, Grinnell College Archives. While Main's defense of academic freedom was laudable, at some other colleges administrators gave way to similar pressures. See Parke Rexford Kolbe, The Colleges in War Time and After (New York, 1918), 102-103 especially.

33. Grinnell Herald, 5 November 1918.

34. Minutes of Grinnell Board of Trustees, Executive Committee, 29 April 1918, Grinnell College Archives. See also the Scarlet and Black, 4 December 1918.

35. On one of the few occasions of Steiner's name appearing in the local press, the Herald graciously noted the publication of his latest book, Uncle Joe's Lincoln, (New York, 1918), and remarked, "It fits into present-day ideals and is designed to teach reverence for the Stars and Stripes and for our martyred President." Grinnell Herald, 20 September 1918. 
to the twenty-member American Immigration Commission, Steiner wanted to live among immigrants to gather information first-hand for his contributions to national policymaking and for his own writing, ${ }^{36}$

$\mathrm{I}_{\mathrm{N}}$ NEw YoRK, during the emotion-filled months of the famous "Red Scare," Steiner again took to the stump to oppose the excesses of post-war prejudice against ethnics and blacks. The hostile responses from his audiences challenged all of the professor's remaining optimism about America. Describing the animosity he encountered, Steiner wrote, "I suddenly realized that the times, and not I, had changed. . . . I was made conscious of it every time I faced an American audience; something had come between us, and we were no longer in rapport." 37

In despair, Steiner turned to his new ethnic neighbors and to writing fiction to work through his grief and sense of alienation. Later in 1919, he published the novel Sanctus Spiritus and Company, which drew heavily upon his own experiences. ${ }^{38}$ The major character was John Hruby, like Steiner born in Austria and an immigrant to America who became a scholar and minister of the gospel. A major influence in Hruby's youth had been the brotherhood and mutual support of three older men in the community - a Catholic, a Protestant, and a Jew. The temper of the times eventually had pitted neighbor against neighbor and friend against friend. Militarism, autocratic government, and ethnic and racial prejudice propelled Hruby to settle permanently in the United States: "No one molests you over there," he told his fellow townspeople during a visit home, "no matter what language you speak."

Hruby eventually became the minister for an ethnic church in a small college town, to which he brought his wife from the Old World. With the outbreak of war, Hruby spiritedly championed the defense of local "hyphenated Americans," joined in

36. Scarlet and Black, 14 December 1918; 12 March, 11 June 1919; The Grinnell Review 14 (January 1919), 43.

37. Edward A. Steiner, Old Trails and New Borders (New York, 1921), 34-35.

38. Edward A. Steiner, Sanctus Spiritus and Company (New York, 1919). 
this endeavor by one newspaper editor and a professor from the college. The other local editor led the attack on the ethnics, and his editorials echoed those of the Capital and the Herald, which had caused such personal distress for Steiner. By December 1917, Hruby himself was a target of suspicion, and the local chapter of the Vigilance Corps pulled him from his home on a snowy night for a hostile interrogation. Embarrassed and outraged at having his loyalty so questioned, Hruby delivered an impassioned speech which drew directly on Steiner's published responses in his own defense. With literary license, the novelist had the minister's pregnant wife tramp through the snow frantically searching for her missing husband that night; the excitement and exposure contributed to a premature birth, and both mother and son died. The Corps' interrogation and the ensuing family tragedy temporarily crushed Hruby's faith in America.

The grieving pastor eventually found solace in a letter from relatives in Europe, delivered after the peace settlement. He learned that in the aftermath of war, this terribly stricken community in Slovakia was being sustained by a new spiritus sanctus and company-Protestant, Catholic, and Jewish women working cooperatively to address the needs of the townspeople. The victims of war-torn Eastern Europe offered a message of hope and inspiration for the more affluent West. An emotional appeal for toleration, mutual respect, and understanding permeated this novel which Steiner wrote from the heart. As he had told his audience in 1916 in defense of the hyphenated Americans, the Old World still had something to give to the New World.

A year later, Steiner returned to Europe to see personally the post-war cooperation in rebuilding. Sponsored by the Friends Service Committee, he traveled widely and recorded his impressions first in essays printed in the New York Independent and later republished and extended in a volume entitled Old Trails and New Borders. The book drew also on his experiences in New York living among immigrants. Dedicated to "my friends," the volume opened with a chapter entitled "The Immigrant's Faith," where Steiner observed, "Happy was the man who was young, a Christian and who lived in America before the war. He wore a triple-plated armour of optimism. He be- 
lieved in progress, in brotherhood, and in himself, to help bring above the new day. ${ }^{39}$

The experiences of the Great War shattered that optimism and confidence for many Americans, immigrant and native. Some entered a long period of despair, went into exile as members of the Lost Generation, and abandoned the program of progressive reform. Some became attracted to more extremist solutions, often nativist in character, and rejected their previous confidence in the will of the democratic majority. ${ }^{40}$ Steiner's message in Old Trails and New Borders, however, was that of a man wearing a new breastplate of confidence, qualified and cautious in his hope, even if no longer clad in a triple-plated armour of optimism. His New York neighborhood of Italian, Bohemian, Polish, and Russian immigrants had restored some faith in the possible good-will and mutual cooperation of men and women of different backgrounds, and Steiner placed more emphasis now on personal action with less confidence in the political structure of the United States. ${ }^{41}$

Edward Steiner continued to share his ecumenical vision of world brotherhood over the next twenty years with his students at Grinnell College, his audiences across Iowa and the nation, and a faithful reading public. He fought numerous additional battles through the 1920s and 1930s for the toleration and internationalism he so dearly espoused. When he retired from teaching in 1941, on the eve of America's entry into another world war, newspapers around the state again gave particular attention to this striking man. His deepest regret and most bitter memory in that spring of 1941 remained the harsh treatment he had received from many townspeople and other Iowans in the hate-filled days of World War I.42

39. Steiner, Old Trails and New Borders, 11.

40. A rich literature exists about the impact of the war on reformers, intellectuals, and churchmen. See, for example, John Higham, Strangers in the Land (New Brunswick, N.J., 1955); Malcolm Cowley, Exile's Return (New York, 1951); and Ronald Steel, Walter Lippman and the American Century (New York, 1980).

41. Steiner, Old Trails and New Borders, 14-15 especially.

42. See, for example, the Des Moines Register, 22 March 1941, and other clippings in the Steiner Papers. 
Copyright of Annals of Iowa is the property of State of Iowa, by \& through the State Historical Society of Iowa and its content may not be copied or emailed to multiple sites or posted to a listserv without the copyright holder's express written permission. However, users may print, download, or email articles for individual use. 